\title{
SỬ DỤNG Hệ THỐNG HÚT ÁP LỰC ÂM (V.A.C.) ĐIỀU TRỊ NHIỄM TRÙNG VÙNG SCARPA SAU PHẪU THUẬT MẠCH MÁU
}

\author{
Dưong Ngọc Thắng*, Nguyễn Hũu Ước*, Vũ Ngọc Tú**, Hoàng Trọng Hải*, \\ Khổng Tiến Bình*, Trần Đăng Thanh*, Thân Thị Nhw*
}

\section{TÓM TÁ̀T}

Mục tiêu: Vùng Scarpa là một đường vào mạch máu thông dụng, tuy nhiên do vị trí giải phẫu và nhiều hệ thống bạch huyết, nên khá hay gặp biến chứng nhiễm trùng vết mổ và rò bạch huyết, đôi khi rất khó điều trị. Báo cáo nhằm đóng góp chỉ định điều trị, đề xuất kỹ thuật thực hiện và chăm sóc đối với các trường hợp nhiễm trùng vùng Scarpa sau phẫu thuật mạch máu.

Đối tượng - phuơng pháp: Nghiên cứu ca lâm sàng tiến cứu một trường hợp có bệnh lý nền phức tạp, bệnh động mạch chi dưới rất nặng, thể trạng béo bệu, bị nhiễm trùng gây biến chứng mạch máu rất khó điều trị sau phẫu thuật tái thông động mạch chậu-đùi phải.

Kết quả: Bệnh nhân nam, 62 tuổi, tiền sử đái đường, tăng huyết áp, phẫu thuật hybrid đặt stent động mạch chậu ngoài, bóc nội mạc động mạch đùi chung và bắc cầu đùi-khoeo phải bằng đoạn mạch nhân tạo PTFE số 8 có vòng xoắn, mổ lại do giả phồng động mạch đùi chung phải, cấy vết mổ có vi khuẩn. Vết mổ vùng bẹn không liền được, nguy cơ tái bục miệng nối mạch máu dẫn đến phải thắt mạch, được chăm sóc bằng hệ thống hút liên tục áp lực âm (VAC) trong 149 ngày, cuối cùng vết mổ liền hoàn toàn, bảo tồn được các cầu nối mạch máu nuôi chi.

Kết luận: Hút áp lực âm liên tục (VAC) là một giải pháp điều trị có hiệu quả, an toàn cho các nhiễm trùng kéo dài của vết thương sau phẫu thuật mạch máu.

Tù khóa: nhiễm trùng vết mổ, Scarpa, hút áp lục âm, phẫu thuật mạch máu.
THE USE OF VACUUM ASSISTED

CLOSURE THERAPY (V.A.C) FOR THE TREATMENT OF INFECTION AT LEVEL OF SCARPA'S TRIANGLE

\section{ABSTRACT}

Objectives: Contribute to treatment indications, techniques and care for Scarpa infections after vascular surgery by vacuum assisted closure (VAC) procedure.

Clinical case: 62-year-old male patient with a history of diabetes, hypertension, hybrid surgery: stenting on the right external iliac artery, endarterectomy of common femoral artery and femoral popliteal bypass with $8 \mathrm{~mm}$ PTFE reinforced vascular graft, re-surgery due to pseudoaneurysm with bacteria of the right common femoral artery. The groin incision wasn't healed, cared by a vacuum assisted closure.

Results: The incision was completely healed after 149 days of treatment.

Conclusion: VAC is a safe technique, brings good results, can be applied for complex infection and fistula at Scarpa site in practice of vascular surgery, and considered as one of the treatment options.

Keywords: wound infection, Scarpa, vacuum assisted closure, vascular surgery.

* Trung tâm Tim mạch và Lồng ngưc, bệnh viện Hũu nghị Việt Đức

** Đại học Y Hà Nội

Nguoòi chịu trách nhiệm khoa học: Dưong Ngọc Thắng

Ngày nhận bài:02/02/2021 - Ngày cho phép đăng: 07/04/2021 


\section{ĐặT VẤN ĐỀ}

Tam giác Scarpa là vị trí thường xuyên được bộc lộ trong phẫu thuật mạch máu vùng dưới dây chằng bẹn. Các vật liệu tự thân (như tĩnh mạch hiển lớn) được sử dụng để tạo hình động mạch (ĐM) hoặc làm cầu nối thì ít gây biến chứng nhiễm trùng hơn so với vật liệu nhân tạo, và nếu có thì tiên lượng cũng tốt hơn [1]. Theo một số nghiên cứu, tỉ lệ nhiễm trùng vùng tam giác Scarpa do vật liệu mạch máu nhân tạo từ $0,5-6 \%$ [2]. Nhiễm trùng vùng Scarpa có liên quan trực tiếp đến hoại tử vùng da, tụ máu sau phẫu thuật do không được dẫn lưu tốt, rò bạch huyết dai dẳng... Các yếu tố nguy cơ bao gồm: phẫu thuật nhiều lần vào vùng Scarpa, béo bệu, sử dụng vật liệu nhân tạo, bệnh lý đái đường, loạn dưỡng cơ. Tại bệnh viện Hữu nghị Việt Đức, có hàng trăm ca phẫu thuật mạch máu được thực hiện mỗi năm, trong đó không hiếm trường hợp nhiễm trùng vùng Scarpa sau mổ. Nhân một trường hợp nhiễm trùng cầu nối mạch nhân tạo phức tạp được điều trị thành công bằng hệ thống hút áp lực âm liên tục (VAC - vacuum assisted closure), không cần phẫu thuật chuyển vạt cơ che phủ, báo cáo nhằm đóng góp về mặt chỉ định điều trị cũng như đề xuất một kỹ thuật chăm sóc đối với các trường hợp nhiễm trùng vùng Scarpa sau phẫu thuật mạch máu.

\section{BÁO CÁO CA LÂM SÀNG}

Bệnh nhân nam 62 tuổi, kỹ sư đã nghỉ hưu, tiền sử đái tháo đường, tăng huyết áp điều trị thuốc uống thường xuyên. Nhập viện ngày 04/10/2019 do tình trạng đau chân phải ngay cả khi nghỉ ngơi. Bệnh nhân được chẩn đoán tình trạng thiếu máu mạn tính giai đoạn III (theo phân loại Leriche - Fontaine) cả 2 chân - trong đó bên phải nặng hơn, trên nền xơ vữa và vôi hóa nặng toàn bộ các động mạch hệ thống. Bệnh nhân được phẫu thuật hybrid đặt stent ĐM chậu ngoài phải, bóc nội mạc $Đ M$ đùi chung và bắc cầu đùi khoeo bằng đoạn mạch nhân tạo PTFE số 8 có vòng xoắn. Ngày thứ 6 sau mổ, bệnh nhân được phẫu thuật lại mở vết mổ, lấy máu cục và làm sạch vết mổ do tụ máu lớn vùng bẹn phải. Bệnh nhân xuất viện ngày 08/11/2019.

Sau 3 tháng, bệnh nhân nhập viện do khối vùng bẹn phải đập theo nhịp mạch, mổ lại ngày 12/02/2020 với chẩn đoán giả phồng động mạch đùi chung phải. Tổn thương xác định trong mổ là bục và chảy máu từ đường khâu nối tạo hình động mạch đùi chung và chậu ngoài phải bằng mạch nhân tạo. Cấy vi khuẩn từ khối giả phồng thấy Corynebacterium amycolatum, tỉ lệ mọc nhiều. Bệnh nhân được điều trị bằng Vancomycin đường tĩnh mạch liều $1 \mathrm{~g} / \mathrm{ngày}$. Sau phẫu thuật vết mổ Scarpa chảy máu, không liền, được chỉ định chăm sóc vết mổ bằng hệ thống hút liên tục áp lực âm (VAC) từ ngày 03/03/2020 (ngày thứ 20 sau mổ), rồi tiếp tục được điều trị ngoại trú, hệ thống được thay và đánh giá lại vết mổ vùng scarpa 2 lần/tuần, ngừng kỹ thuật vào ngày 30/07/2020 (ngày 149). Đánh giá vết mổ khô, liền sẹo hoàn toàn, bệnh nhân được kết thúc quá trình điều trị. 

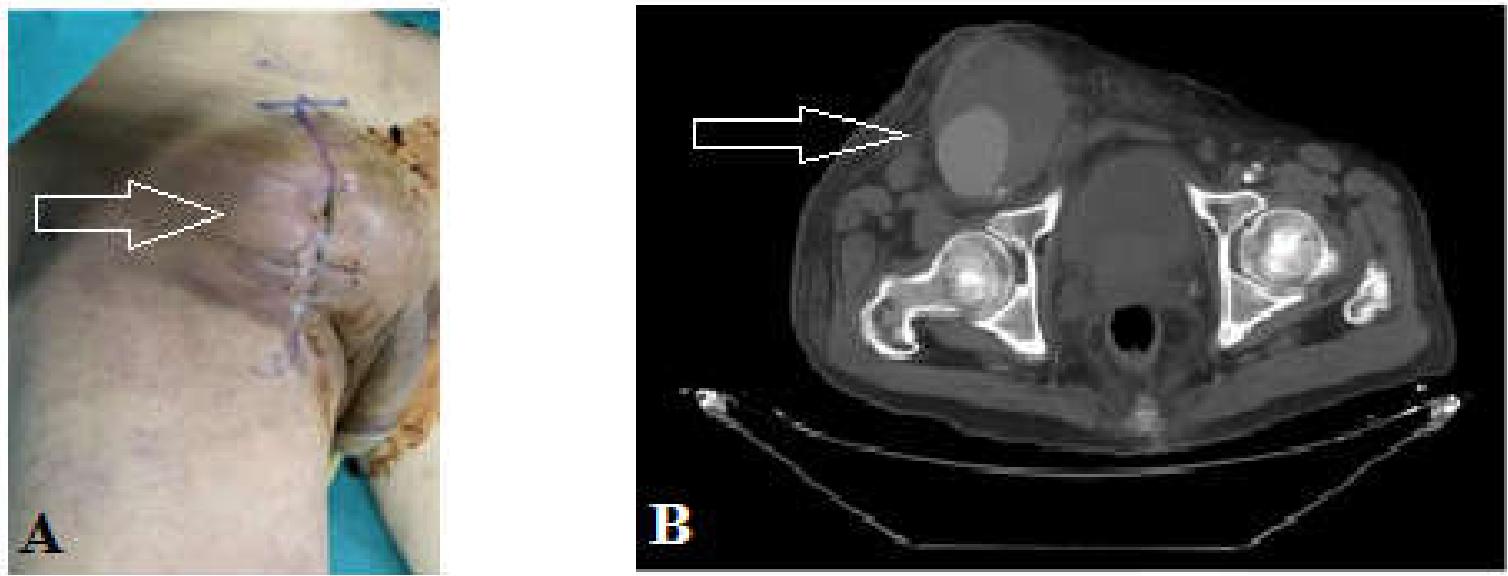

Hình 1. Khối giả phồng động mạch đùi chung phải - trên lâm sàng (A); trên MSCT (B) B. Khối giả phồng trên phim chụp cắt lớp vi tính đa dãy
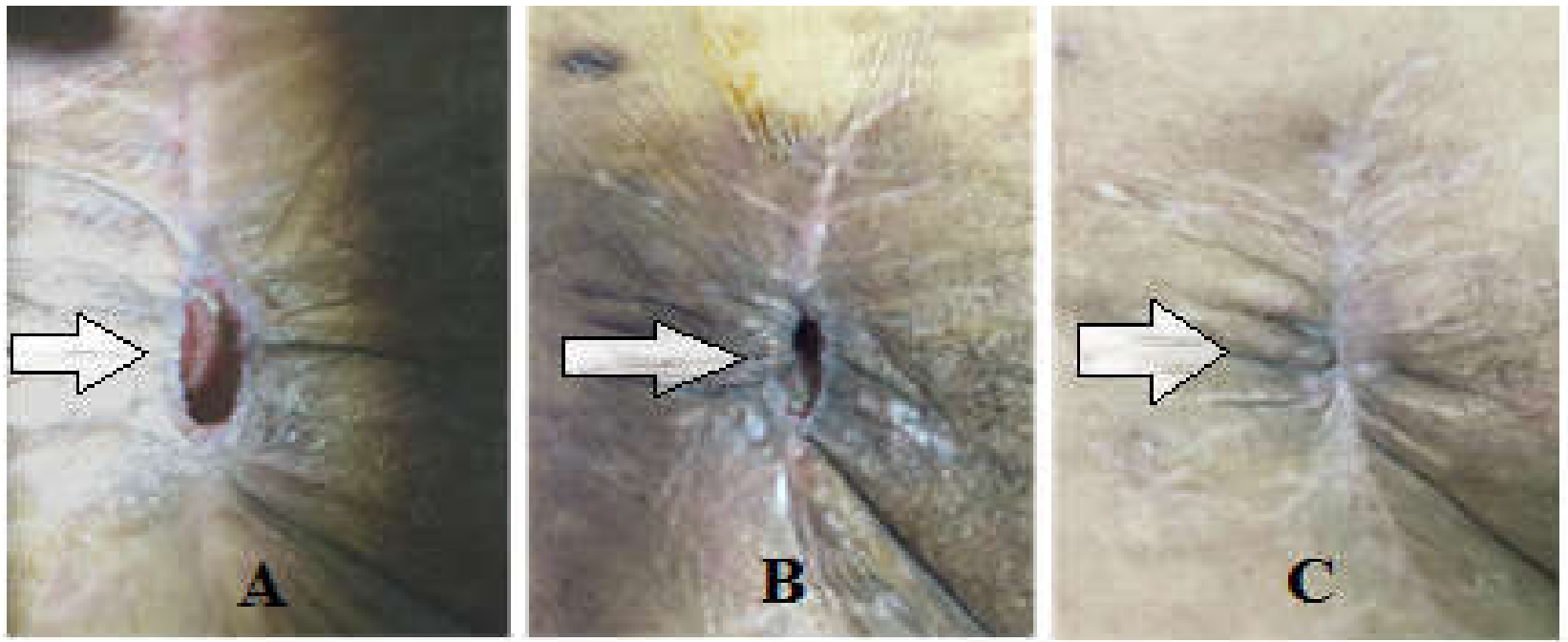

Hình 2. Vết mổ vùng bẹn phải sau đặt hệ thống VAC: Ngày 48 (A); Ngày 52 (B); Ngày 12 sau ngùng $\operatorname{VAC}(C)$.

\section{BÀN LUẬN}

Nhiễm trùng vật liệu ghép mạch vùng Scarpa sau các phẫu thuật mạch máu dưới dây chằng bẹn được coi như thảm họa của phẫu thuật mạch máu do tỉ lệ cắt cụt chi cũng như tử vong rất cao [3]. Nhiều nghiên cứu đã chỉ ra các yếu tố nguy cơ bao gồm: yếu tố từ bệnh nhân - tuổi cao, giới tính nam, BMI cao, suy tim, suy giảm miễn dịch, đái đường, suy thận, bệnh phổi tắc nghẽn mạn tính, nhiễm khuẩn huyết tại thời điểm phẫu thuật, tổn thương loét $\mathrm{da}$, thời gian nằm viện trước phẫu thuật dài [4]; yếu tố liên quan đến phẫu thuật: tiêm thuốc cản quang chụp mạch trong mổ, kỹ thuật rạch da vùng Scarpa, tính chất phẫu thuật (kéo dài, cấp cứu, mổ lại), phẫu tích tổ chức rộng rãi, tổn thương mạch và hạch bạch huyết trong mổ [5]; yếu tố sau phẫu thuật: nhiễm trùng vết mổ, tụ máu hoặc tụ dịch dẫn đến giả phồng mạch hoặc chảy máu vết mổ [6]. 
Theo phân loại của Szilagyi [1] hoặc Samson [7] về nhiễm trùng vật liệu ghép mạch máu (Bảng 1), thì ca bệnh này ở mức độ 3 theo Szilagyi và mức độ 4 theo Samson.

Bảng 1. Phân loại nhiếm trùng vật liệu ghép mạch máu [1], [7]

\begin{tabular}{|c|l|l|}
\hline Độ & \multicolumn{1}{|c|}{ Theo Szilagyi } & \multicolumn{1}{|c|}{ Theo Samson } \\
\hline 1 & Nhiễm trùng chỉ khu trú ở lớp da & Nhiễm trùng chỉ khu trú ở lớp da \\
\hline 2 & $\begin{array}{l}\text { Nhiễm trùng lan vào tổ chức dưới da nhưng } \\
\text { chưa lan vào mảnh ghép mạch máu }\end{array}$ & $\begin{array}{l}\text { Nhiễm trùng lan vào tổ chức dưới da nhưng } \\
\text { chưa lan vào tổ chức mô tiếp xúc trực tiếp với } \\
\text { mảnh ghép mạch }\end{array}$ \\
\hline 3 & Nhiễm trùng lan vào mảnh ghép mạch máu & $\begin{array}{l}\text { Nhiễm trùng lan vào mảnh ghép mạch máu } \\
\text { nhưng chưa lan vào miệng nối mạch máu }\end{array}$ \\
\hline 4 & $\begin{array}{l}\text { Nhiễm trùng lan vào miệng nối mạch máu } \\
\text { nhưng chưa có nhiễm khuẩn huyết hoặc chảy } \\
\text { máu do bục miệng nối }\end{array}$ \\
\hline 5 & $\begin{array}{l}\text { Nhiễm trùng miệng nối mạch gây nhiễm } \\
\text { khuẩn huyết hoặc bục miệng nối. }\end{array}$ \\
\hline
\end{tabular}

Tại Trung tâm Tim mạch và Lồng ngực bệnh viện Hữu nghị Việt Đức, đã và đang áp dụng lưu đồ được sử dụng rộng rãi ở các trung tâm phẫu thuật mạch máu tại Pháp [8] để điều trị cho các bệnh nhân có nhiễm khuẩn vùng Scarpa sau phẫu thuật mạch máu (Hình 3). Ca bệnh trong nghiên cứu có nhiễm trùng vùng Scarpa bên phải gây lộ mạch nhân tạo và được chỉ định bảo tồn cầu nối do cầu nối vẫn thông tốt. Chỉ định hợp lý cho bệnh nhân là phẫu thuật chuyển vạt cơ che phủ mạch nhân tạo và chăm sóc vết thương, với tỉ lệ thành công lên đến $90 \%$ theo các nghiên cứu [9]. Tuy nhiên, tỉ lệ nhiễm trùng tái phát có thể lên tới $35 \%$ và có một số bệnh nhân không phù hợp với kỹ thuật này đặc biệt là những bệnh nhân trong tình trạng toàn thân nặng, nhiều bệnh phối hợp, suy dinh dưỡng nặng. Ca bệnh của chúng tôi có thể trạng béo, nhiều bệnh lý nền, vùng bẹn có nhiều tổ chức xơ hóa do phẫu thuật nhiều lần, tiên lượng phẫu thuật chuyển vạt cơ che phủ mạch nhân tạo khó khăn, nên chúng tôi quyết định sử dụng hệ thống hút áp lực âm liên tục (VAC) làm liền vết thương.

Chăm sóc vết thương sử dụng hệ thống VAC là phương pháp được Argenta và Morykwas sử dụng lần đầu tiên năm 1989 [10]. Đây là kỹ thuật điều trị không xâm lấn đối với các vết thương mạn tính bằng cách tạo áp lực âm hút liên tục (từ 55 đến $200 \mathrm{mmHg}$ ) lên vết thương liên tục 24/24h, cho phép tổ chức mô hạt mọc lấp đầy khoang trống của vết thương để có thể thực hiện tiếp các kỹ thuật điều trị che phủ da. Cơ chế tạo điều kiện thuận lợi cho sự phát triển của tổ chức hạt gồm [11], [12]: làm giảm phù nề và tiết dịch từ vết thương; hạn chế sự phát triển của vi khuẩn nhất là vi khuẩn Gram(-); cải thiện tuần hoàn mạch máu và bạch huyết, tăng cường sự oxy hóa tại chỗ. Theo nghiên cứu của Morykwas và Argenta, với áp lực hút âm 125 mmHg, lưu lượng máu cấp cho mô tăng gấp 4 lần so với không hút áp lực [13]. 
Theo kinh nghiệm chung trên thế giới, chỉ định của phương pháp VAC đối với nhiễm khuẩn vùng Scarpa sau phẫu thuật mạch máu gồm có: giả phồng động mạch đùi nhiễm trùng được vá mạch bằng tĩnh mạch hiển hoặc mạch nhân tạo, nhiễm trùng sau phẫu thuật bóc nội mạc động mạch đùi và vết mổ nhiễm trùng lộ cầu nối tĩnh mạch hoặc mạch nhân tạo. Với phương pháp chăm sóc vết thương nhiễm trùng bằng $\mathrm{VAC}$ - không phẫu thuật chuyển vạt cơ, tỉ lệ thành công lên đến 75\% [14]. Tuy nhiên một trong những nhược điểm của phương pháp VAC là có thể gây tổn thương mạch máu hoặc cầu nối khi hút trực tiếp lên thành mạch trong những trường hợp tổn thương lộ mạch máu. Để khắc phục nguy cơ này, chúng tôi đã sử dụng vật liệu đệm Mépitel (loại miếng dán silicon mỏng được phủ polyamide) ngăn cách giữa mạch nhân tạo và tấm xốp polyurethane của hệ thống. Theo nghiên cứu của $\mathrm{S}$.Acosta [15] và Dosluoglu [16], không ghi nhận biến chứng mạch máu do kỹ thuật này và kết quả tương đối tốt. VAC cũng được sử dụng như một phương pháp chăm sóc vết thương tạm thời trước phẫu thuật chuyển vạt cơ với mục đích kéo dài thời gian hồi sức, chăm sóc dinh dưỡng và kiểm soát tình trạng nhiễm trùng với kháng sinh đường tĩnh mạch.

\section{Lưu đồ điều trị nhiễm khuẩn vùng Scarpa sau phẫu thuật mạch máu}

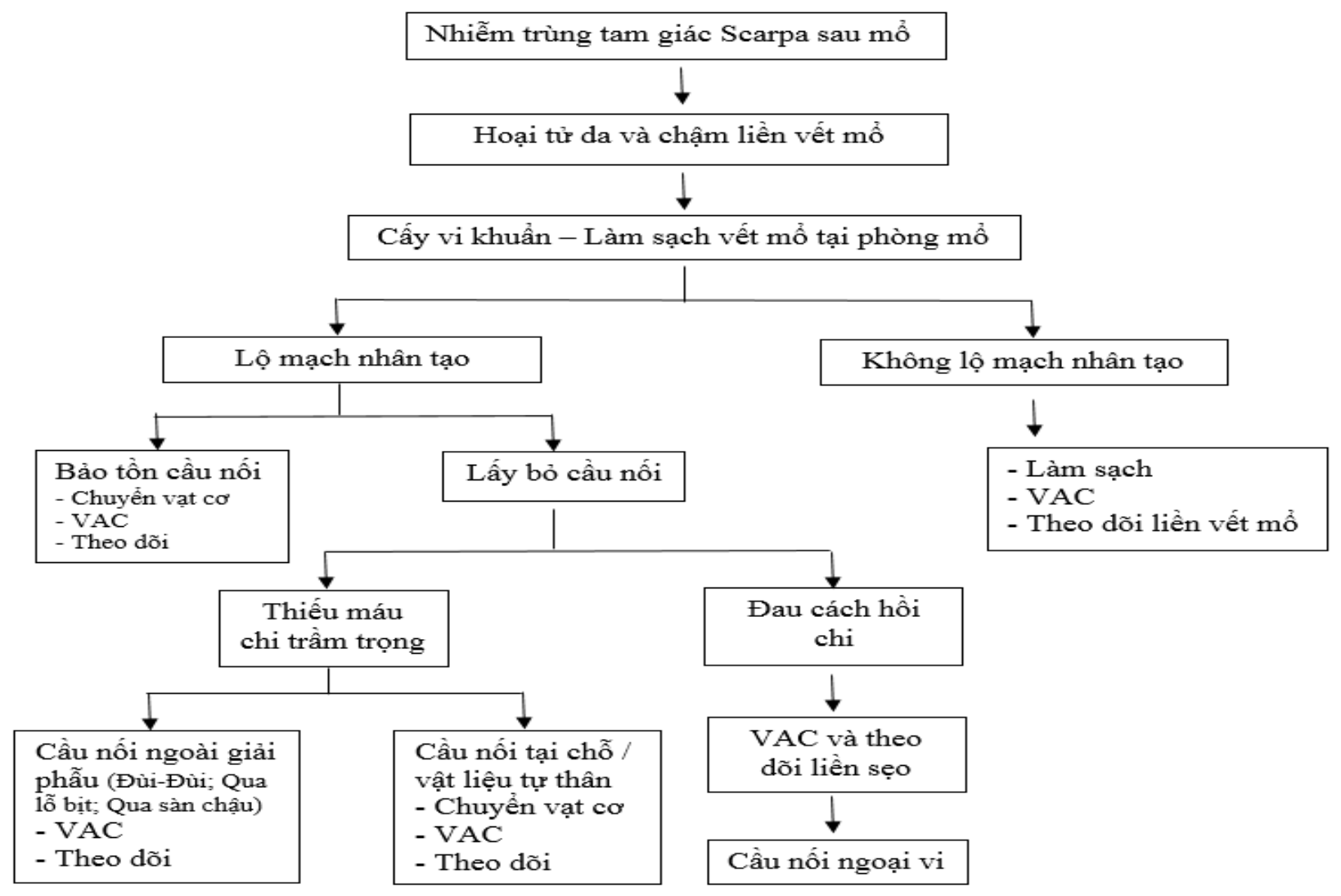

Hinh 3. Luu đồ điều trị nhiếm khuẩn vùng Scarpa sau phẫu thuật mạch máu [8] 
Báo cáo của chúng tôi mới chỉ thực hiện trên một bệnh nhân nên chưa có cơ hội so sánh về thời gian điều trị tại bệnh viện cũng như giá thành điều trị bằng phương pháp sử dụng hệ thống VAC đơn thuần so với các kỹ thuật khác. Mặc dù vậy, dựa trên các nghiên cứu trên thế giới và kinh nghiệm trong quá trình điều trị cho bệnh nhân, chúng tôi nhận định đây là kỹ thuật an toàn, đem lại kết quả tốt nhưng phụ thuộc rất nhiều vào sự kiên trì điều trị của cả bệnh nhân và thầy thuốc.

\section{KẾT LUẬN}

Dựa trên các kết quả nghiên cứu trên thế giới và kinh nghiệm trong quá trình điều trị cho ca lâm sàng bị nhiễm trùng phức tạp vùng tam giác Scarpa sau phẫu thuật mạch máu, chúng tôi nhận định VAC là kỹ thuật an toàn, đem lại kết quả tốt, có thể ứng dụng trong điều kiện thực tiễn của chuyên ngành ngoại mạch máu. Tuy nhiên phương pháp này phụ thuộc rất nhiều vào sự kiên trì điều trị của cả bệnh nhân và bác sĩ.

\section{TÀI LIỆU THAM KHẢO}

1. Szilagyi DE, Smith RF, Elliott JP et al. (1972). Infection in arterial reconstruction with synthetic grafts. Ann Surg, 176,321-333.

2. Demaria RG, Giovannini UM, Teot L et al. (2003). Topical negative pressure therapy. A very useful new method to treat severe infected vascular approachs in the groin. J Cardiovasc Surg (Torino), 44,757-761.

3. Barbara Hasse, Lars Husmann, Annelies Zinkernagel et al. (2013). Vascular graft infections. Swiss Med Wkly, 143,1-7.
4. Antonios VS, Noel AA, Steckelberg JM et al. (2006). Prosthetic vascular graft infection: a risk factor analysis using a case-control study. J Infect, 53,49-55.

5. Bandyk DF (2008). Vascular surgical site infection: risk factors and preventive measures. Semin Vasc Surg, 21,119-123.

6. Nagpal A, Sohail MR (2011). Prosthetic vascular graft infections: a contemporary approach to diagnosis and management. Curr Infect Dis Rep, 13,317-323.

7. Samson RH, Veith FJ, Janko GS et al. (1988). A modified classification and approach to the management of infections involving peripheral arterial prosthetic grafts. J Vasc Surg, 8, 147-153.

8. Ricco J.B, Probst H. (2008). Complications précoces des revascularizations artérielles sous inguinales, Techniques chirurgicales-Chirurgie vasculaire, EMC, Paris.

9. Taylor SM, Weatherford DA, Langan EM et al. (1996). Outcomes in the management of vascular prosthetic graft infections confined to the groin: a reappraisal. Ann Vasc Surg, 10,117-112.

10. Argenta L.C, Morykwas M.J. (1997). Vaccum assisted closure: a new method for wound control and treatment. Ann Plast Surg, 38,563-576.

11. Morykwas M.J., Simpson J., Punger K. et al. (2006). Vacuum assisted closure: state of basic research and physiologic foundation. Plast Reconstr Surg, 117,121-126. 
12. Moues C.M, Vos C.M, Van den Bemd infected lower extremity bypass grafts. Ann G.J et al. (2004). Bacterial load in relation to vacuum assisted closure wound therapy: a prospective randomized trial. Wound repair Regen, 12,11-17.

13. Morykwas M.J, Argenta L.C (1997). Nonsurgical modalities to enhance healing and care of soft tissue wounds. J South Orthop Assoc, $6,279-288$.

Vasc Surg, 8,31-37.

15. S. Acosta, C. Monsen (2012). Outcome after VAC Therapy for Infected Bypass Grafts in the Lower Limb. Euro Jour of vasc and endovasc surg, 44,294-299.

16. HH. Dosluoglu, DK. Schimpf, R. Schultz et al. (2005). Preservation of infected and exposed vascular grafts using vacuum assisted

14. Calligaro KD, Veith FJ, Sales CM et al. (1994). Comparison of muscle flaps and closure without muscle flap coverage. Jour of vasc surg, 42,989-992. delayed secondary intention wound healing for 